\title{
ПЕРВЫЕ НАФТОМЕТРЫ ДЛЯ ОПРЕДЕЛЕНИЯ ТЕМПЕРАТУРЫ ВСПЫШКИ ЖИДКОСТЕЙ. 3. ПАРОВЫЕ ТЕСТЕРЫ
}

\author{
С. Г. Алексеев, В. В. Смирнов, К. А. Зарипова, Н. М. Барбин
}

СЕРГЕЙ ГЕННАДЬЕВИЧ АЛЕКСЕЕВ - кандидат химических наук, доцент, научный консультант автономной некоммерческой организации «Уральский научно-исследовательский институт Bсероссийского добровольного пожарного общества»,E-mail: 3608113@mail.ru.

ВИТАЛИЙ ВЛАДИМИРОВИЧ СМИРНОВ - старший преподаватель кафедры пожарной безопасности в строительстве Уральского института государственной противопожарной службы МЧС России.

КСЕНИЯ АНАТОЛЬЕВНА ЗАРИПОВА - эксперт автономной некоммерческой организации «Уральский научно-исследовательский институт Всероссийского добровольного пожарного общества», аспирант Научно-инженерного иентра «Надежность и ресурс больших систем и машин» УрО РАН.

НИКОЛАЙ МИХАЙЛОВИЧ БАРБИН - доктор технических наук, доиент, ведущий научный сотрудник научно-исследовательского отдела Уральского института государственной противопожарной службы МЧС России, директор научно-исследовательского института физических и химических проблем и техносферной безопасности Уральского государственного аграрного университета.

620137, Свердловская область, г. Екатеринбург, ул. Учителей 32. АНО «Уральскийнаучно-исследовательский институт ВДПО».

620062, Свердловская область, г. Екатеринбург, ул. Мира, д. 22. Уральский институт ГПС МЧС России.

620049, Свердловская область, г. Екатеринбург, ул. Студенческая 54А. Научно-инженерный иентр «Надежность и ресурс больших систем и машин» УрО РАН.

620075, Свердловская область, г. Екатеринбург, ул. Карла Либкнехта, д. 42. Уральский государственный аграрный университет.

Американская нефтяная револючия 1859 года и изобретение керосиновой лампь способствовали наступлению керосиновой эры, когда свечное освещуение было замено керосиновым. Побочным эффектом этого явился рост пожаров и взрывов из-за применения небезопасного керосина. В связи с этим возникла потребность в разработке критериев безопасного керосина. Такими показателями выступили температура вспышки и воспламенения. Первый этап создания приборов для определения этих показателей начался в 1862 году и закончился в начале 20-го столетия. Он характеризуется разработкой аппаратов различных конструкиий, одной из которых являются паровые тестеры. В статье рассматриваются первые нафтометры (Саллерона-Урбана, Вандер Вейда, Блэра, Мюзела, Буассона, Гейслера, Либэманна, Стоддарда, Бейльштейна, Мака, Бернштейна, Брауна, Райта, Майяра, Майяра-Хоялера, Хаасса, Абельянца и Брэдли-Хэйла). Эти аппарать не дожили до наших дней, однако идеи, заложенные в эти аппарать, с успехом используются в настоящее время.

Ключевые слова: керосин, нефтепродукт, температура вспышки, температура воспламенения, нафтометр, аппарат, прибор, тестер, пирометр. 


\title{
FIRST NAPHTOMETERS FOR DETERMINATION OF FLASH POINT OF LIQUIDS 3. VAPOR TESTER
}

\author{
S. G. Alexeev ${ }^{1,2}$, V.V. Smirnov', K.A. Zaripova ${ }^{3}$, N. M. Barbin ${ }^{2,4}$ \\ ${ }^{1}$ Science and Engineering Centre "Reliability and Safety of Large Systems and Machines" of Ural Branch of RAS. \\ ${ }^{2}$ Ural Institute of State Fire Service of EMERCOM of Russia, Yekaterinburg, Russia. \\ ${ }^{3}$ Science and Engineering Center «Reliability and Safety of Large Systems and Machines» of the Ural Branch of the RAS. \\ ${ }^{4}$ Institute of Physical and Chemical Problems and Technosphere Safety of Ural State Agrarian University.
}

The American oil revolution of 1859 and the invention of a kerosene lamp contributed to the onset of the kerosene era when candle lighting was replaced by kerosene. The side effect of this was the growth of fires and explosions due to the use of unsafe kerosene. There was a need to develop criteria for safe kerosene. The fire (burning) and flash point of kerosene were chosen as such indicators. The first stage of creating instruments to determine these indicators began in 1862 and ended at the beginning of the 20th century. This stage is characterized by the development of apparatuses of various designs, one of which were vapor testers. The first naphthometers (Salleron-Urbain, Vander Weyde, Blair, Meusel, Byasson, Geissler, Liebermann, Stoddard, Beilstein, Mack, Bernstein, Braun, Wright, Meyer, Meyer-Hörler, Haass, Abelianz and Bradley-Hale) are considered in the article. These devices have not survived to our day and are undeservedly forgotten, however, the ideas embodied in the principle of operation of these devices are being successfully used at present.

Keywords: kerosene, oil product, flash point, fire point, naphtometer, apparatus, device, tester, pyrometer.

Ранее отмечалось [1-6], что изобретение керосиновой лампы в 1853 году львовскими аптекарями Яном Зехом (Jan Zeh) и Игнатием Лукасевичем (Ignacy Łukasiewicz) и появление на рынке дешевого керосина, обусловленного американской нефтяной революцией 1859 года, создали условия для наступления керосиновой эры, когда керосиновое освещение сменило свечное. Однако массовое применение керосиновых приборов способствовало не только прогрессу, но привело также к росту пожаров и взрывов, обусловленных их несовершенством и применением небезопасного керосина, поэтому возникла необходимость не только в усовершенствовании керосиновых ламп и керогазов, но в выборе лимитов (критериев) для безопасного керосина, а также создании приборов для их экспериментального определения. В 60-е годы 19-го столетия в Великобритании и в ряде штатов США на официальном уровне были приняты лимиты безопасного керосина на основе температуры вспышки или воспламенения, а в конце 19-го столетия они были уже во всех ведущих странах, включая Российскую империю [3-5]. В 1862 году появились первые нафтомертры ${ }^{1}$ сэра Фредери-

\footnotetext{
${ }^{1}$ В 1860-1920-е г.г. термины: нафтометр, прибор, аппарат, пирометр и тестер для определения температуры вспышки (воспламенения) рассматривались, как синонимы. Этот подход сохранен в настоящей работе.
}

ка Августа Абеля (Frederick Augustus Abel) [7-9], Хорейса Смита (Horace J. Smith) и Вудруфа Джонca (Woodruff Jones) [10], Джона и Джузеппе Тальябу (John and Giuseppe Tagliabue) [11, 12], Эдварда Парриша (Edward Parrish) [13-15], Антонио Касартелли (Anthony Casartelli) [16], Сиднея Гиббонса (Sydney Gibbons) [17] и др. для определения температур вспышки и воспламенения. ${ }^{2}$ Появление данных тестеров спровоцировало бум по созданию новых и модернизации имеющихся аппаратов в разных странах. К концу 19-го столетия уже насчитывалось порядка 100 различных приборов и их модификаций для определения температуры вспышки [19], которые можно разбить на 6 типов:
1. открытый тигель;
2. полузакрытый тигель;
3. паровые аппараты
4. закрытый тигель;
5. нафтометры дистилляционного типа;
6. комбайн.

\footnotetext{
${ }^{2}$ В отчете специального агента бюро переписи населения департамента внутренних дел США (Census Bureau of Department of the Interior) С.Ф. Пекхэма (S.F. Peckham) от 1885 года отмечено, что первые эксперименты по определению температуры вспышки в США были проведены профессором Н.П. Хиллом (N.P. Hill) и ассистентом Алленом (Allen) в университете Брауна (Brown University) в 1861 году [18]. Однако им не дается описание тестера Хилла-Аллена и не приводится ссылка на источник, в котором опубликованы результаты исследования Хилла и Аллена.
} 
В предыдущих сообщениях ${ }^{3}$ [6] были рассмотрены приборы типов: открытый и полузакрытый тигли. Объектом настоящего исследования являются паровые нафтометры для определения температуры вспышки. Данные аппараты можно разделить на два класса: тестеры без источника зажигания и с источником зажигания. ${ }^{4}$

\section{Приборы без источника зажигания}

В 19-м столетии, если не вдаваться в детали [2], под температурой вспышки жидкости (осветительного масла, керосина и т.п.) понималась наименьшая температура, при которой вспыхивают её пары, а под температурой воспламенения минимальная температура, при которой возникает горение самой жидкости [21]. При этом температура вспышки рассматривалась как критерий взрывоопасности горючей жидкости, а температура воспламенения как параметр её пожарной опасности [2]. Таким образом, исследователями 19-го столетия предполагалось, что для осуществления вспышки паров осветительного масла (керосина) необходимо образование достаточного количество её горючих паров. В переводе на современный язык это означает, что вспышка происходит при концентрации паров $\left(\mathrm{C}_{\mathrm{rn}}\right)$ не ниже нижнего концентрационного предела воспламенения (НКПВ). ${ }^{5}$ Принцип действия паровых приборов без источника зажигания построен на способе фиксации температуры, при которой, по мнению изобретателей, концентрация $\mathrm{C}_{\text {гп }}$ будет либо равна НКПВ, либо незначительно выше НКПВ. Преимуществом данного косвенного метода является отсутствие применения запального пламени, что повышает его пожарную безопасность $[25,26]$.

В 1866 году французские исследователи М.Дж. Саллерон (M.J. Salleron) и В. Урбан (V. Urbain)

\footnotetext{
3 Часть 2 (полузакрытый тигель) выйдет в Российском химическом журнале в 2019 г.

${ }^{4}$ В работе [20] дана иная классификация паровых нафтометров - закрытые паровые аппараты и открытые или закрытые приборы с насыщенным паром. По мнению авторов, её нельзя признать удачной, поскольку она не в полной мере отражает принцип их работы.

5 Показатель пожаровзрывоопасности НКПВ берет свое начало от работ английского химика сэра Хемфри Дэви (Humphry Davy) по изучению рудничного газа и созданию безопасной масляной лампы для горняков [22-24]. До конца 19 века исследования по определению КПВ в основном касалось только горючих газов, поэтому термин взрывные пределы, так первоначально назывались пределами взрываемости и при оценке пожаровзрывоопасности керосина и других легковоспламеняющихся и горючих жидкостей (ЛВЖ/ГЖ), а также при классификации ЛВЖ и ГЖ они не использовались $[1,3,5]$.
}

впервые предложили практическую реализацию данного подхода для контроля пожарной опасности керосина. На рисунке 1 представлена первая версия нафтометра. Порядок работы на тестере Саллерона-Урбана заключается в следующем: снимают крышку с поворотного блока $\mathbf{4}$ и наливают 50 мл воды в медный или латунный тигель 1 , затем поворотный блок 4 переводят в положение «закрыто» (резервуар для керосина $\mathbf{5}$ не сообщается с дыркой 6 в крышке тигля 1), после чего резервуар 5 заполняют тестируемым минеральным маслом (керосином) и поворотный блок закрывают крышкой.

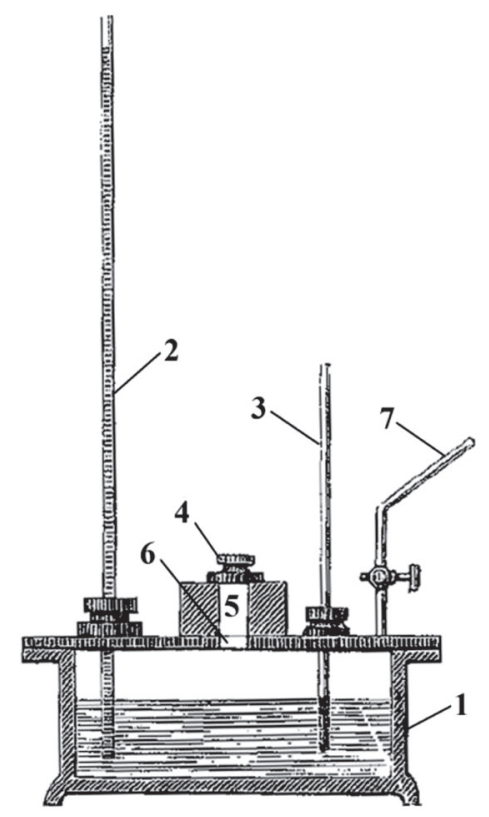

Рис. 1. Первый вариант аппарата Саллерона-Урбана [28-31]

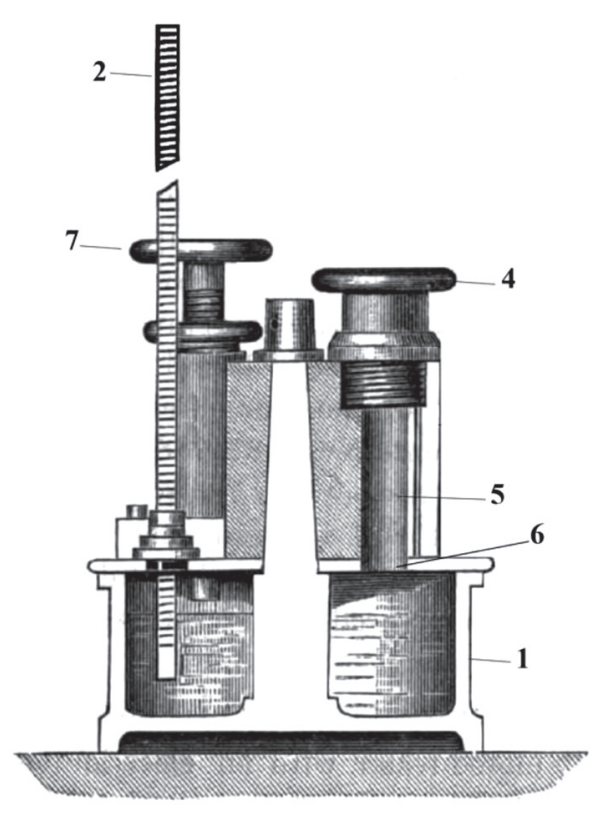

Рис. 2. Фабричная модель тестера Саллерона-Урбана $[8,9,32-36]$ 


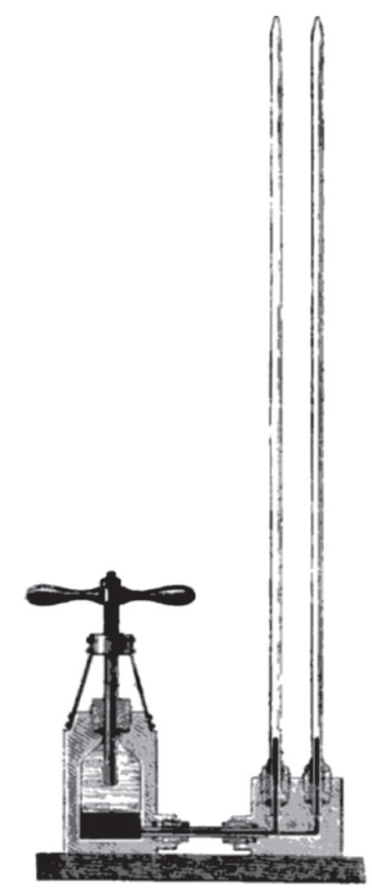

Рис. 3. Демонстрационный прибор Пуллета [40]

Прибор помещают в водяную баню, которая используется в качестве термостата. После стабилизации температуры бани и водяной подушки в тигле 1 с помощью небольшого штока, установленного в трубке 7, устанавливают уровень воды в манометре 2 на отметке «0» и изменением положения поворотного блока 4 вносят тестируемую пробу в тигель 1. На основании контрольных тестов установлено, что для безопасного керосина давление водяного столба не должно превышать 64 мм вод. ст. при температуре $15{ }^{\circ} \mathrm{C}$ [27-31].

В коммерческой модели порядок работы на нафтометре сохранен, изменен только вид и расположение некоторых узлов прибора (рис. 2). В 19-м столетии данный аппарат применялся во Франции в качестве официального тестера для оценки качества (безопасности) нефтепродуктов. Ограниченное его применение имело место и в других странах, включая Россию и США [8, 9, 32-39]. В качестве недостатка прибора Саллерона-Урбана отмечалось, что неплотности в подгонке различных движущихся частей прибора сильно сказываются на точности измерения $[9,35]$. Также незаслуженно отмечалось, что тестер Саллерона-Урбана всего лишь является модификацией прибора Пуллета (Pouillet's Apparat) [31]. Из простого сравнения этих аппаратов, приведенных на рисунках 1-3, видно, что повышение давления в паровоздушном пространстве достигается разными способами.

В 1870 году Питер Х. Вандер Вейд (Peter H. Vander Weyde) запатентовал в США паровой нафтометр, который состоит из стеклянной камеры $\mathbf{3}$, за-

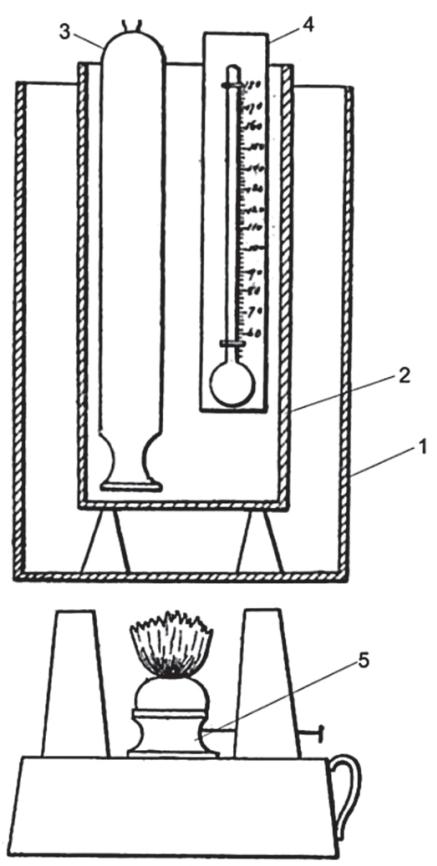

Рис. 4. Тестер Вандер Вейда [41]

паянной с одного конца, диаметром не более 1 дюйма и длиной шесть дюймов, двух водяных бань 1 и $\mathbf{2}$, термометра 4 и спиртовки 5 (рис. 4) [41, 42].

Для испытания горючей жидкости стеклянная трубка 3 до краев наполняется тестированным осветительным маслом (керосином), отверстие в трубке закрывается пальцем испытателя, переворачивается, погружается на дно сосуда 2, заполненного водой и погруженного в водяную баню 1.

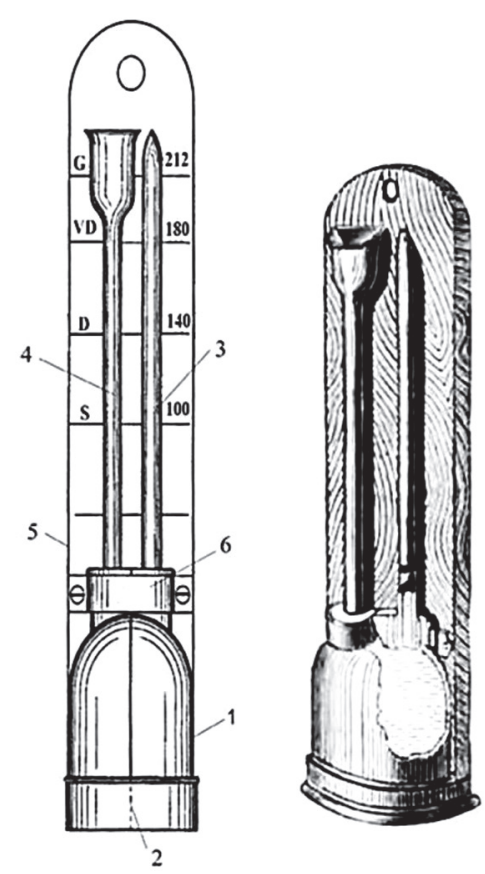

Рис. 5. Прибор Блэра (а) $[42,43]$ 
Нагрев осуществляется с помощью спиртовки $\mathbf{5}$, а контроль температуры осуществляется термометром 4. Пары керосина начинают собираться в верхней части стеклянной трубки 3 . Температура воды в сосуде 2 , при которой начинается образования парового пузыря в трубке 3, по мнению Вандер Вейда, соответствует значению температуры вспышки исследуемого керосина [41, 42].

В 1873 году Джоном Блэром (John Blair) предложен аппарат для установления контрафактного керосина (рис. 5). Идея работы аппарата Блэра основана на предположении, что увеличение объема испытуемого керосина при нагревании происходит пропорционально объему содержащихся легкокипящих соединений. Для оценки безопасности осветительного масла (керосина) используется эталонная жидкость, в связи с этим стеклянный резервуар 1 разделен перегородкой 2 на две емкости для образцов эталона и тестируемой жидкости. В этих емкостях имеются горлышки для установки в них с помощью резиновых пробок стеклянных трубок 3 и 4 длиной 6 дюймов и диаметром $1 / 8$ дюйма. С помощью кожаного или матерчатого хомута 6 прибор крепится к основанию 5. Перед проведением испытаний осуществляется калибровка прибора. Для этого в стеклянный резервуар 1 устанавливается незапаянная трубка 3 и наливается эталонный керосин до нижней отметки на этой трубке. Затем резервуар 1 нагревают на водяной бане. При достижении температуры до $212^{\circ} \mathrm{F}$ нагрев прекращают, на трубке 3 делают отметку по уровню эталонной жидкости и верхний конец трубки 3 запаивают. При естественном охлаждении резервуара 1 в водяной бане на трубке 3 дополнительно отмечают уровни столба эталонной жидкости при температурах 180, 140 и $100^{\circ} \mathrm{F} .6$ После охлаждения резервуара 1 до комнатной температуры к нему присоединяют трубку 4, через которую заливают тестируемую жидкость до уровня эталона. Затем данную конструкцию крепят к основанию 5 с помощью хомута 6. Для удобства работы на лицевой стороне опоры наносится шкала, которую также можно обозначить информационными знаками: Safe (безопасный), Danger (опасный), Very Danger (очень опасный) и Gas (газ, пар). Резервуар 1 нагревают на водяной бане и в интервале температур от 100 до $212^{\circ} \mathrm{F}$ фиксируют высоту и скорость

6 На момент изобретения прибора Блэра лимит для безопасного керосина в штате Пенсильвания США, в котором проживал изобретатель, составлял не 100, а 110 F [35]. По всей видимости, Дж. Блэр ориентировался британский лимит, равный $100{ }^{\circ} \mathrm{F}$ [9], поскольку в 19-м столетии Британская империя была основным импортером американского керосина.

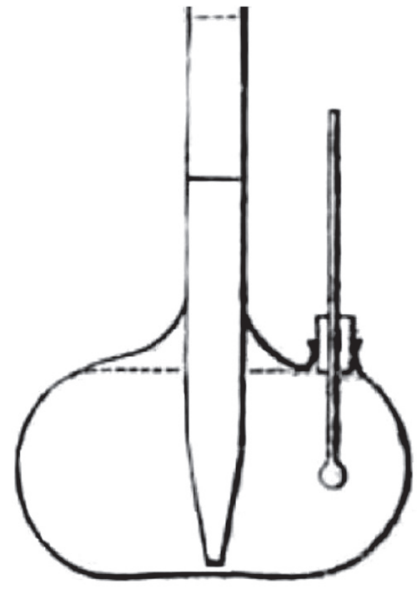

Рис. 6. Тестер Мюзела [44]

подъема тестируемого образца и эталона. Если качество испытуемого керосина ниже эталонного, то его скорость подъема и высота уровня жидкости также будет больше чем у эталона, а температура его вспышки будет ниже уставленного лимита для безопасного керосина $[42,43]$.

В качестве прототипов аппарата Блэра можно рассматривать нафтометры Эд. Мюзела (Ed. Meusel) и M.Х. Буассона (M.H. Byasson). Прибор Мюзела представляет 150 мл стеклянную колбу $\mathbf{1}$, к которой приварены мерная трубка и горло для установки термометра (рис. 6). При проведении

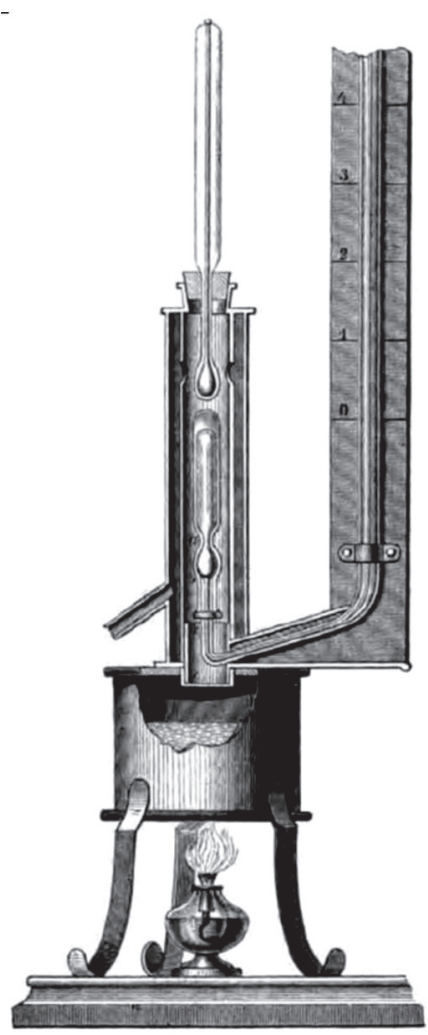

Рис. 7. Парометр Гейслера [48] 


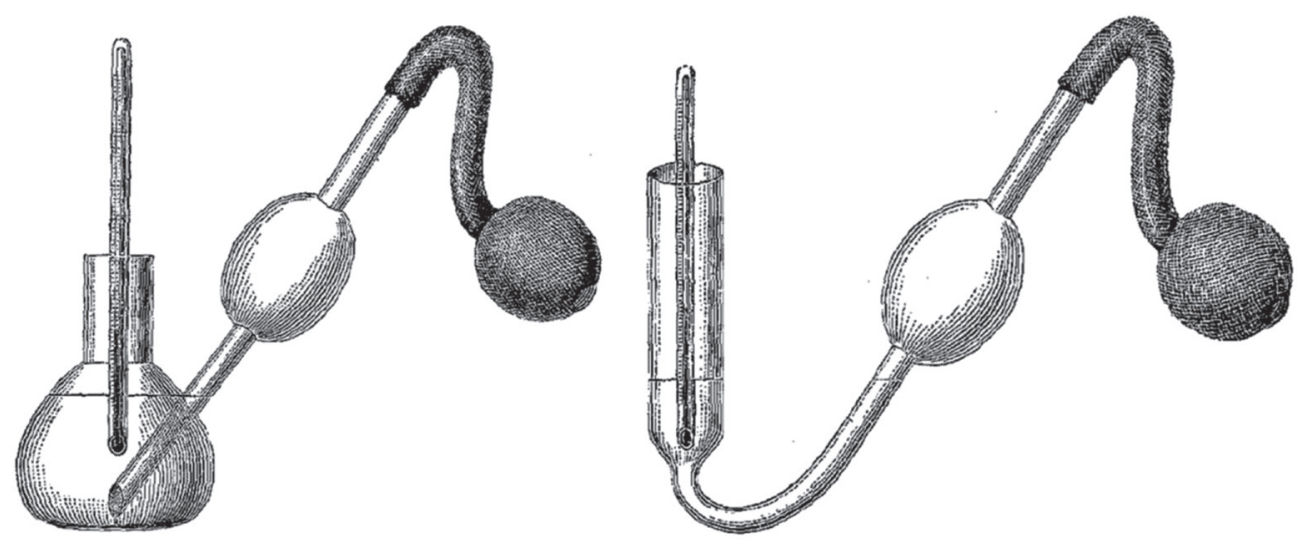

Рис. 8. Паровые нафтометры Либэманна [49]

испытаний нагрев установки осуществляется на водяной бане [44-46]. В докладе М.Х. Буассона [47] не приведено описание конструкции его прибора образца 1865 года, отмечено только, что оценка пожаровзрывоопасности керосина осуществляется по высоте водяного столба.

В справочнике Боллея (Bolley's Handbuch) 1879 года предлагается осуществлять контроль безопасности осветительных масел с помощью парометра Гейслера (Geissler vaporimeter), который был разработан для контроля алкогольной продукции (рис. 7). Принцип действия аппарата Гейслера аналогичен вышерассмотренным нафтомерам. Отличие заключается в том, что давление насыщенного пара определяется по высоте ртутного, а не водяного столба [48].

\section{Приборы с источником зажигания}

Нафтометры данного класса можно разделить на три подкласса: А (открытые), Б (полузакрытые) и С (закрытые).

В приборах подкласса А перед тестом на вспышку применяется кратковременный или постоянный барботаж воздуха для интенсификации образования паровой фазы. Первые тестеры, работающие на данном принципе, были предложены Лио Либэманном (Leo Liebermann) в 1882 году [49]. На рисунке 8 приведены эти аппараты без водяной бани, ${ }^{7}$ которые изготовлены на базе 100 мл плоскодонной стеклянной колбы и стеклянной пробирки диаметром 1,5-2,0 см и высотой $10 \mathrm{~cm}$. Барботаж воздуха в этих нафтометрах осуществляется через стеклянную трубку с помощью резиновой груши. В качестве запала используется пламя лучины. Несмотря на различные объемы тестируемого керосина тестеры, представленные

\footnotetext{
7 Также допускалась нагревание на воздушной бане [49].
}

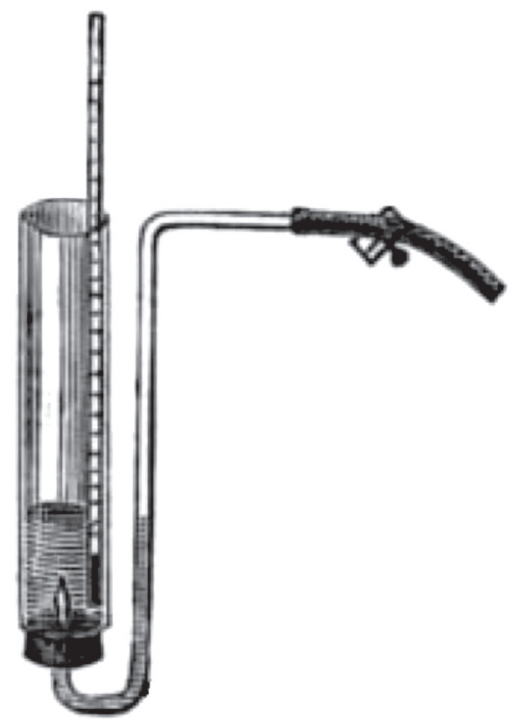

Рис. 9. Тестер Стоддарда [50, 51]

на рисунке 8, дают сопоставимые результаты испытаний на вспышку. Следует отметить, что второй вариант нафтометра Либэманна фабрично выпускался компанией «Calderoni \& Co.» в Будапеште во второй половине 19-го столетия [49], что указывает на практическое его применение в АвстроВенгерской империи.

В 1882 году тестер Либэманна был модифицирован Джоном Стоддардом (John T. Stoddard), который вставил стеклянную трубку через корковую пробку. Диаметр стеклянной трубы увеличен до 2,0-3,0 см при её высоте 10-12 см (рис. 9) [50-52]. Для интенсификации образования паровой фазы керосина осуществлялся постоянный барботаж воздуха через слой керосина. Данная конструкция аппарата Стоддарда применялась в учебном процессе в США в начале 20-го столетия [53].

В 1883 году русским химиком Федором Федоровичем Бейльштейном (Feodor F. Beilstein) де- 


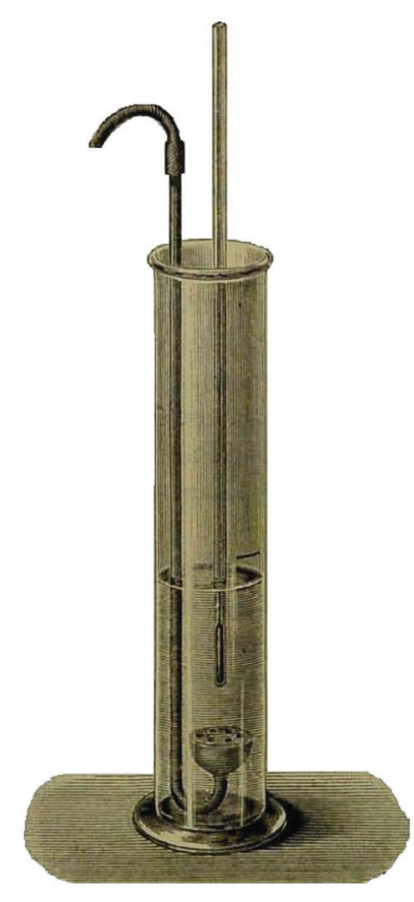

Рис. 10. Лабораторный вариант тестера Бейльштейна без водяной бани $[33,34,36,54,55]$

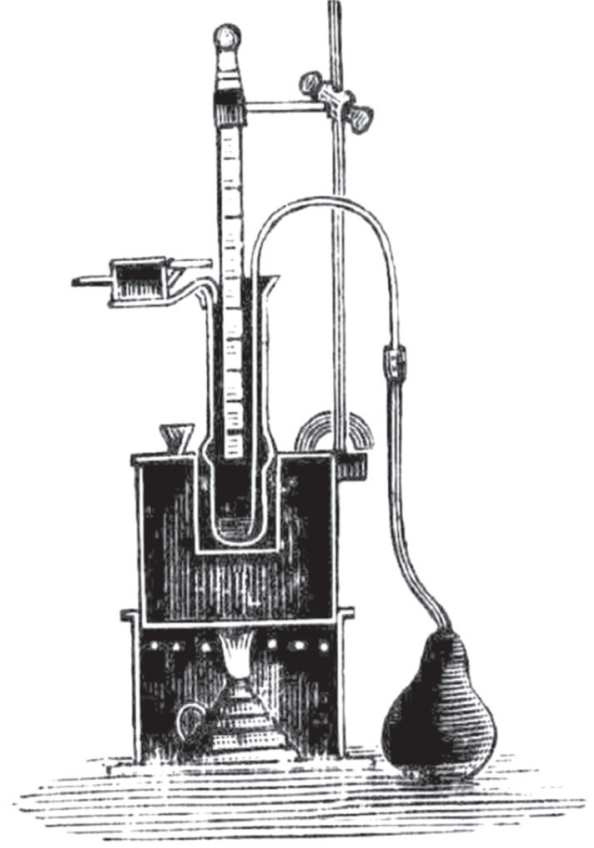

Рис. 11. Коммерческий вариант нафтометра Бейльштейна $[59,57]$ тально изучены методы определения вспышки по Либэманну и Стоддарду и сделан ряд критических замечаний, ${ }^{8}$ которые касались размеров аппаратов, свободного пространства масляного цилиндра, скорости и времени барботажа воздуха [49-51]. Им также предложен собственный простой и дешевый прибор для определения температуры вспышки, состоящий из стеклянного масляного цилиндра $35 \times 175$ мм и латунного барботера с головкой, как у душевой лейки. Конструкция барботера обеспечивает образование мелких воздушных пузырей (рис. 10). На цилиндре имеется две отметки на расстоянии 60 и 70 мм от его дна [33, 34, 36, 54-59].

Принцип работы прибора Бейльштейна следующий: в масляный цилиндр наливают тестируемый керосин или другую горючую жидкость до нижней отметки и устанавливают термометр. Нагревают на водяной бане со скоростью $0,3 \div 0,5$ град/мин. Перед тестом на вспышку через слой керосина пропускают 5 унций воздуха с помощью газгольдера или резиновой груши для обеспечения слоя пены 10 мм. Затем подносят небольшое запальное пламя. Если вспышки не произошло, то тест на вспышку повторяют через 1 градус [54, 57, 60].

В коммерческой версии аппарата Бейльштейна (рис. 11) допускалось использование масляного

\footnotetext{
${ }^{8}$ В последующем Стоддардом был проведен цикл дополнительных экспериментов для устранения этих замечаний [61].
}

цилиндра с нижней его частью из латуни или меди [54, 57, 60]. Инженер-технологом В.К. Долининым проведен сравнительный анализ определения температуры вспышки на приборах Тальябу, Синтениса (Sintenis), Пэриша, Энглера (Engler), Майяра-Хоялера (Meyer-Hörler), Хaаca (Haas), АбеляПенского (Abel-Pensky) и Бейльштейна. Установлено, что прибор Бейльштейна, при его использовании подготовленным экспериментатором, не уступает лучшим нафтометрам, за исключением прибора Абеля-Пенского. Им был сделан вывод, что модернизация данного тестера способствовала бы более широкому его применению на практике [60]. Однако правительство Российской империи отдало предпочтение наиболее совершенным на тот момент времени приборам Абеля-Пенского и Пенски-Мартенса (Pensky-Martens), для которых были отработаны методы их поверки и нормирован процесс проведения испытаний $[62,63]$, поэтому тестер Бейльштейна имел ограниченное применение в России. В американской учебной литературе для студентов химиков начала 20-го столетия встречается упрощенная версия нафтометра Бейльштейна [64].

В 1923 году перед американскими исследователями встала задача смоделировать такой прибор, при котором вспышка горючей жидкости происходила на нижнем концентрационном пределе воспламенения. При решении данной проблемы они фактически дали вторую жизнь открытым тестерам насыщенного пара. Прибор Э. Мака 


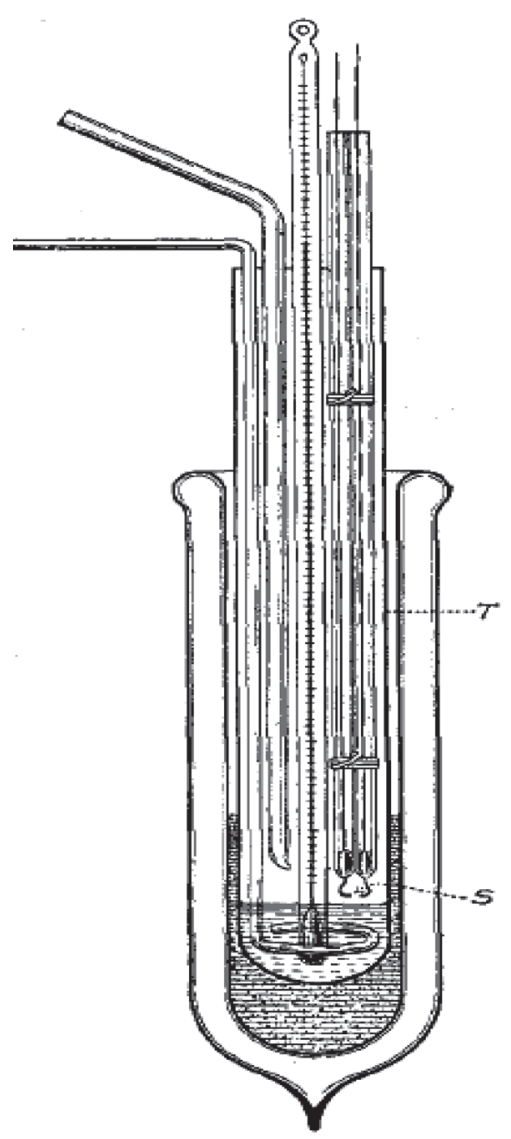

Рис. 12. Аппарат Мака [65]

(Е. Mack) представлен на рисунке 12. Он состоит из запаянной с одного конца стеклянной трубки $\mathbf{T}$, в которую залита испытуемая жидкость и помещены платиновый источник искрового разряда $\mathbf{S}$, и две стеклянные трубки для барботажа сухого воздуха и газоотводной трубки. Данная конструкция помещена в сосуд Дьюара. Для проведения экспериментов при температуре ниже комнатной температуры используется охлаждающая смесь (ацетон + сухой лед), а для определения температуры вспышки выше комнатной температуры применяется горячая вода [65].

К аппаратам подкласса Б относятся тестеры полузакрытого типа, в которых предусмотрена механическое или автоматическое частичное выдавливание паровой фазы горючей жидкости из пространства тигля.

Наиболее известным представителем нафтометром данного подкласса является аппарат Алекca Бернштейна (Alex Bernstein). На рисунках 13 и 14 представлены два варианта этого прибора [9, 32, 33, 35-37, 66-68]. В Европе и Америке распространение получила модели со встроенным источником зажигания (рис. 14a-в). Прибор Бернштейна со встроенным источником зажигания состоит из $\mathrm{U}$-образной системы труб с тиглем 2 и отво-
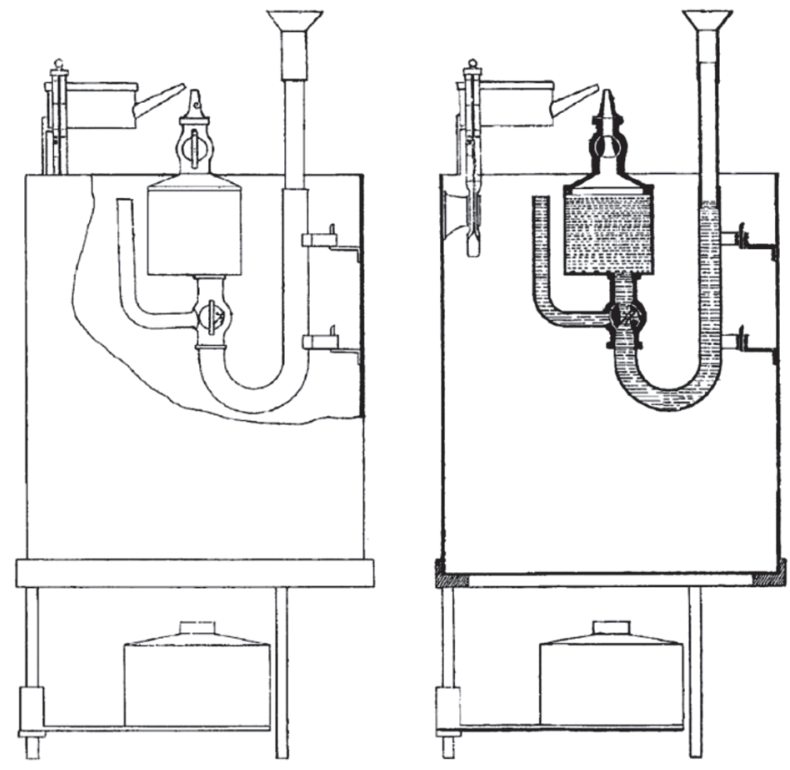

Рис. 13. Тестер Бернштейна с внешним источником зажигания [66]

дной трубки $\mathbf{3}$, кранов 8 и 7, двух термометров 4, водяной бани 1 и спиртовки 5. В крышке тигля 2 имеется две трубки для установки запального фитиля и для выхода паров испытуемой жидкости (рис. 14в).

Перед испытанием тигель 2 заполняют тестируемой жидкостью при закрытом трехходовом кране 7. Через воронку 6 U-образная трубка наполняется водой до переливания воды через отводную трубку 3. Кран 8 закрывают, а кран 7 переводят в положение, в котором он перекрывает отводную трубку 7 и тигель 2. В нагретую водяную баню 1 до температуры, равной лимиту для безопасного керосина, помещается прибор Бернштейна. При необходимости для нагрева дополнительно используют спиртовку 5. После выравнивания температур в бане $\mathbf{1}$ и в тигле $\mathbf{2}$ открывают краны 7 и 8. Вода, стекая вниз, поднимает уровень масла в тигле и вытесняет паровоздушную смесь через паровую трубку в крышке тигля 2. Далее экспериментатор фиксирует факт вспышки или её отсутствие [9, 32-37, 39, 67, 68].

В 1880 году немецким исследователем О. Брауном (O. Braun) предложен близкий по принципу действия прибор «дайвер» (“Taucher” нем.) для экспресс анализа безопасности осветительных масел. Перед тестированием резервуар 1 заполняют тестируемым керосином $\sim 1 / 3$ его объема через трубку 2 с помощью переходной муфты и воронки. Прибор помещают в водяную баню 4 , предварительно нагретую до температурного лимита безопасности керосина. Зажигают запальную горелку 6 и держатель 3 вместе с установкой кратковременно опускают 


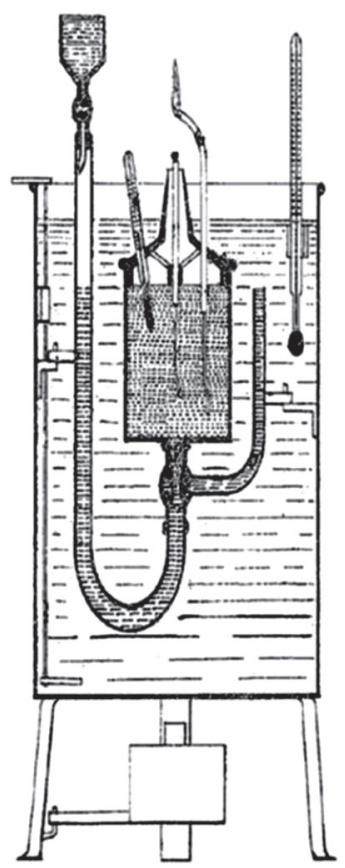

a

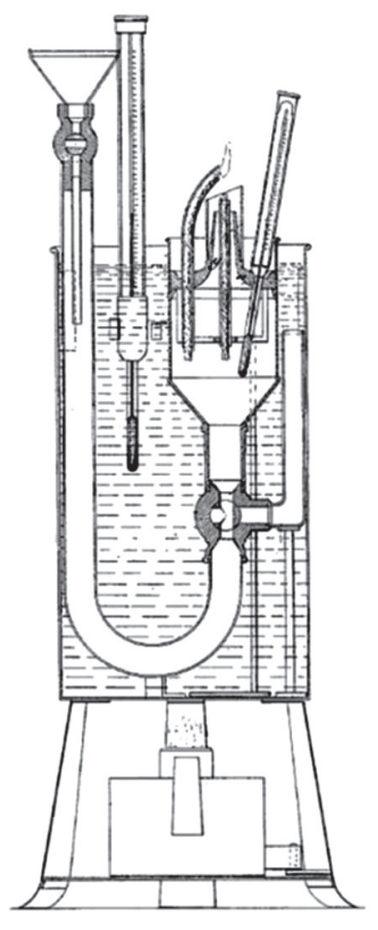

6

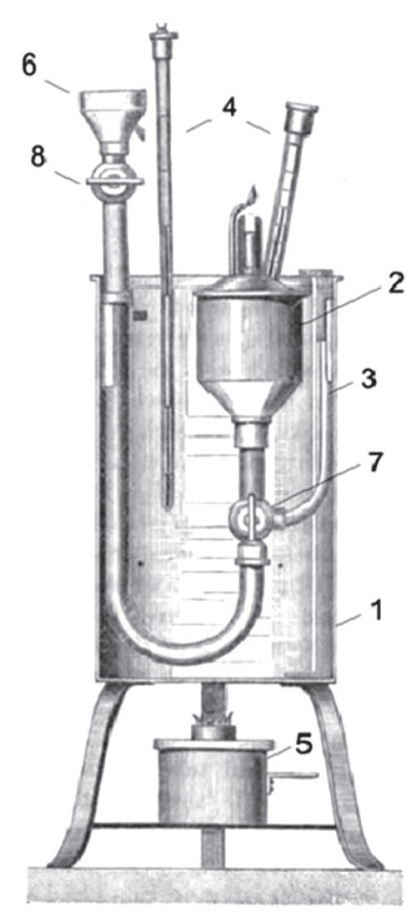

B

Рис. 14. Аппарат Бернштейна со встроенным источником зажигания $[9,32,33,35-37,67,68]$. а-немецкий вариант, б-американский вариант, в-общий вид

на дно. Небольшая порция воды через трубку 2 попадает в резервуар 1 и вытесняет часть паровоздушного пространства через отводную трубку $\mathbf{5}$. Если вспышки не происходит, то тестируемый об-

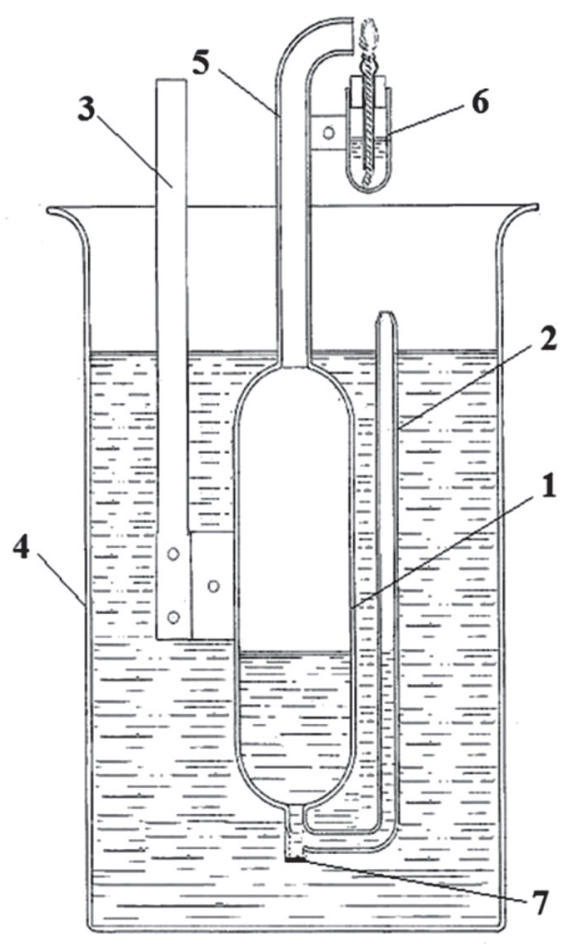

Рис. 15. «Дайвер» Брауна [69] разец выдержал огненный тест (fire test) и относится к категории безопасных осветительных масел. Для слива тестируемого образца и воды предусмотрена пробка 7 [69].

В 1922 году английским исследователем Робертом Райтом (Rober Wright) предложена установка для определения температуры вспышки (рис. 16), которую можно рассматривать, как дальнейшее развития аппаратов Лейберманна, Стоддарда и Бейльштейна. Данный прибор состоит

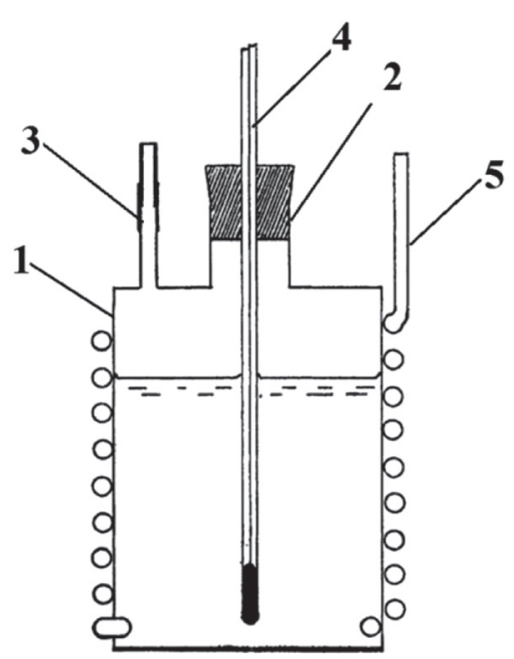

Рис. 16. Прибор Райта 
из медного цилиндра 1 диаметром 55 мм и высотой 75 мм. В верхней его части установлены две трубки $\mathbf{2}$ и $\mathbf{3}$ для термометра $\mathbf{4}$ и отвода паров. Цилиндр 1 по спирали обмотан медной трубкой $\mathbf{5}$, которая входит вовнутрь тигля $\mathbf{1}$ в нижней его части. Внутри цилиндра 1 трубка 5 замкнута в круг, в котором имеется ряд мелких дырок (отверстий). Для проведения испытаний в тигель 1 наливают 100 мл тестируемой жидкости и устанавливают термометр 4. Конец трубки 2 защищают с помощью трубки с силикагелем. На вход трубки 5 устанавливают хлоркальциевую трубку. Нагрев осуществляется со скоростью 1 градус в 15 минут в 2-х литровой водяной бане с периодическим перемешиванием воды в бане. С интервалами через 2 минуты нагрев прекращают и кратковременно пропускают сухой воздух через трубку $\mathbf{5}$, после чего подносят запальное пламя к силикагелевой трубке, соединенной с медной трубкой 2 . При отсутствии вспышки эксперимент продолжается [70].

К приборам подкласса Б также относятся нафтометры Джорджа Сэйболта (George M. Saybolt) [71], тестеры О. Брауна с массивным тиглем [9, 72, 73], А. Эренберга (А. Ehrenberg) [55], которые были рассмотрены во второй части нашей серии работ. ${ }^{3}$

Метод Виктора Майяра (Victor Meyer) фактически является родоначальником семейства аппаратов подкласса В. По запросу полицейского управления кантона Цюриха им был проведен ряд экспериментов по установлению «реальной» (минимальной) температуры вспышки керосина и других легковоспламеняющихся жидкостей, в результате которых в 1879 году предложена следующая методика: 200 мл стеклянный цилиндр с 40 мл керосина закрытый пробкой с термометром нагревают в тепловой воде до достижении температуры керосина и водяной бани $36^{\circ} \mathrm{C}$. Затем цилиндр удаляется из водяной бани, энергично встряхивается, пробка удаляется и вносится запальное пламя газовой горелки. В зависимости от результата на вспышку эксперимент повторяют либо при пониженной, либо повышенной на 1 градус температурах до нахождения минимальной температуры, при которой наблюдается вспышка $[36,39,58,74,75]$. В последующем сотрудником лаборатории профессора Майяра господином Г. Хоялером (H. Hörler) этот метод был усовершенствован. Отличие заключается в следующем: для тестирования используется 300 мл стеклянный цилиндр, заполненный на 1/10 объема исследуемой жидкостью, закрытый пробкой с двумя термометрами для измерения температуры жидкости и паровоздушного пространства и тестирование начинается при температуре $40{ }^{\circ} \mathrm{C}$. Данный метод официально использовался для контроля безопасности по температуре вспышке керосина и других горючих жидкостей в Швейцарии $[34,74,75]$.

Другими модификацией нафтометра Майяра является аппараты P. Хaacca (R. Haass) и Абельянца (Abelianz). Прибор Хаaса (рис. 16) состоит из стеклянного цилиндрического тигля с откидной крышкой из меди, который помещен в латунную или медную воздушную баню. В аппарате также имеется специальное устройство, обеспечивающее изменение положения тигля по высоте в воздушной бане. Тестер Хаасса оснащен двумя термометрами для измерения температуры исследуемой жидкости и воздушной бани (последний не показан на рис. 17). В качестве источника зажигания использованы два платиновых электрода. Нагрев воздушной бани осуществляется с помощью спиртовки на глиняной тарелке. Методика испытаний на данном нафтометре заключается в следующем: тигель с тестируемым осветительным маслом (керосином) и помещают в предварительно нагретую воздушную ванну. Затем постепенно повышают температуру, регулируя положение спиртовки и глубину погружения тигля в воздушную ванну, чтобы разница между воздушным и масляным термометрами не превышала $5{ }^{\circ} \mathrm{C}$. При достижении необходимой температуры, нагрев прекращают, прибор интенсивно встряхивают несколько раз и после осаждения пены пропускают искру в течение 1 с. В случае отсутствия вспышки процесс проведения испытания повторяют при повышенной температуре [9, 34, 39, 76-78].

В 1880 году на конференции химического общества в Цюрихе был представлен прибор швейцарского химика Харутюна Абелянца (Haruthiun Abeljanz), который состоит из стеклянного ци-

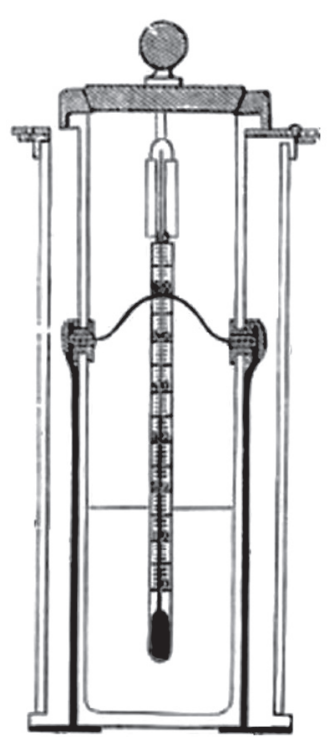

Рис. 17. Прибор Хаасса $[9,34,77,78]$ 


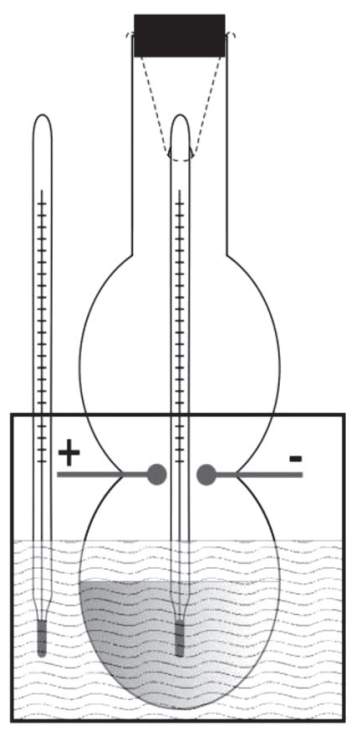

Рис. 18. Нафтометр Абелянца кой, оснащенной ручной мешалкой, термометром и платиновыми электродами. Для сброса избыточного давления при вспышке на крышке тигля смонтированы два открывающихся клапана (рис. 19). Процедура испытаний не отличается от методов Абеля и Абеля-Пенского, за исключением применения электроподжига [9, 32, 82, 83].

В приборе М.Э-П. Думаноса (M. É-P. Dumanois) в качестве источника зажигания использована автомобильная свеча. Масляный тигель, по аналогии с прибором Энглера, оборудован открывающимся клапаном для сброса избыточного давления (рис. 20a) [84].

В лабораторных целях для определения температуры вспышки использовался эдиометр Хофманна (Hofmann'sches Eudiometer), который представляет собой U-образную трубку, оснащенную электродами, термометром и двумя кранами (рис. 20б). Перед испытанием прибор заполняется на полови-
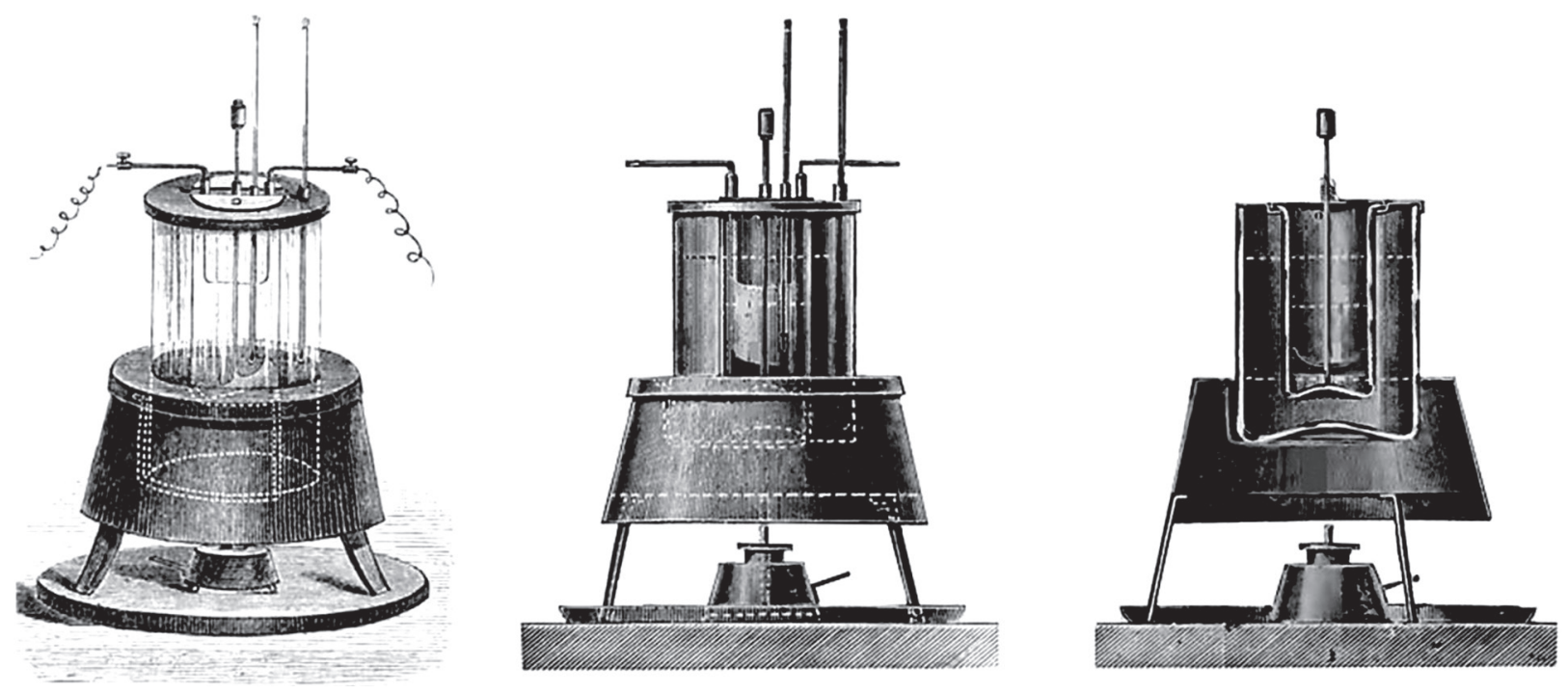

Рис. 19. Электрический аппарат Энглера $[9,32,82,83]$

линдра $12 \times 3$ см. Нижняя часть которого выполнена из двух шаров объемом по 70 мл (рис. 18). В качестве пробки используется толстый слой жевательной резинки. Нагрев осуществляется на водяной бане. В качестве источника зажигания, как и в приборе Хаасса, используется электроподжиг. При вспышке тестируемого керосина происходит вскрытие пробки тигля [79-81]. Тестер Абелянца применялся в качестве официального прибора для контроля безопасности керосина в швейцарском кантоне Цюриха [80].

Электрический тестер Энглера, является развитием метода Хacca (Haass), и он состоит из медной водяной бани, в которой установлена стеклянная водяная баня со стеклянным тиглем с крыш- ну пробой керосина, далее производится нагрев с помощью спиртовки, перед тестом на вспышку прибор несколько раз интенсивно встряхивается, открывается верхний кран и пропускается электрическая искра. В случае отказа повторяют выше описанные операции до достижения вспышки паров керосина [85].

В 1882 году Френсис Пис (Francis S. Pease) на базе своего открытого тестера [6] предложил конструкцию закрытого парового тестера с одновременным электроподжигом горючей паровоздушной смеси в нескольких местах (рис. 20в) [86].

Возможно, к классу закрытых паровых аппаратов для определения температуры вспышки относится и портативный прибор Скотта (Scott) 


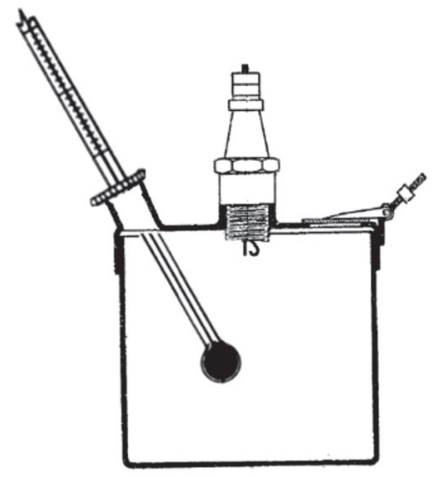

a

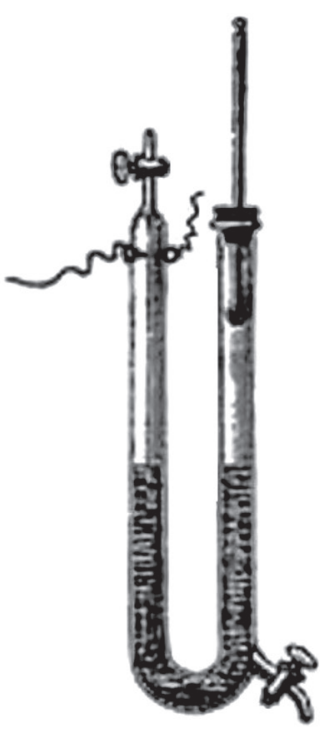

б

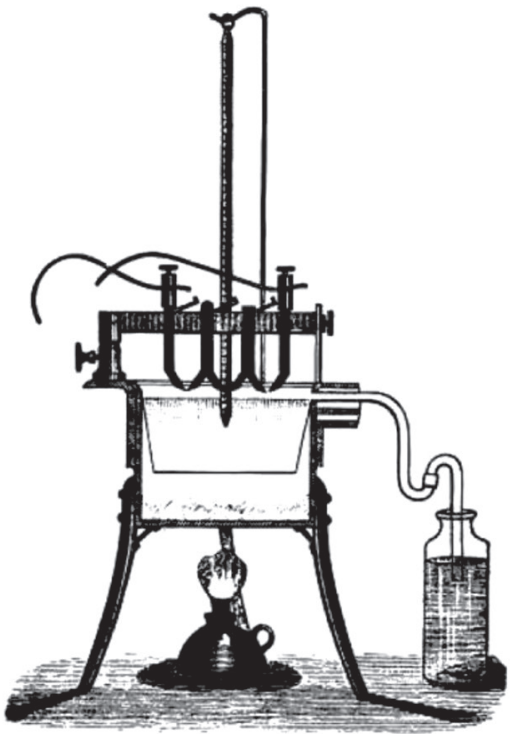

B

Рис. 20. Тигель прибора Думаноса (а) [84], эдиометр Хофманна (б) [85], тестер Писа (в) [86]

(рис 21a). Несмотря на то, что он выпускался фабрично доступной информации о нем немного. ${ }^{9}$ Его особенностью является наличие аккумуляторной батареи, присоединенной непосредственно к рабочей части прибора [87-89]. В конструкции аппарата Скотта просматривается его сходство с нафтометром полузакрытого типа (рис. 21б), который широко использовался в 1870-е годы во Франции [90].

${ }_{9}^{9}$ В описании и на рисунке прибора $[87,88]$ не отмечено, какой способ сброса избыточного давления в нем заложен (предохранительный клапан или постоянно открытое отверстие).
В 1909 году В.П. Брэдли (W.P. Bradley) и C.Ф. Хэйла (C.F. Hale) на аппарате собственной конструкции фактически определили нижнюю и верхнюю границу температуры вспышки и давление взрыва паровоздушной смеси керосина. Прибор Брэдли-Хэйла состоит из толстостенного латунного цилиндра 1 13,5×7,5 см и объемом 560 мл, который оснащен манометром 2, металлическим чехлом для термометра $\mathbf{5}$, электроподжигом $\mathbf{6}$, барботером 3 и газоотводной трубки 7 с кранами 4 (рис. 22). При тестировании заливают в аппарат 390 мл керосина и нагревают на водяной бане.

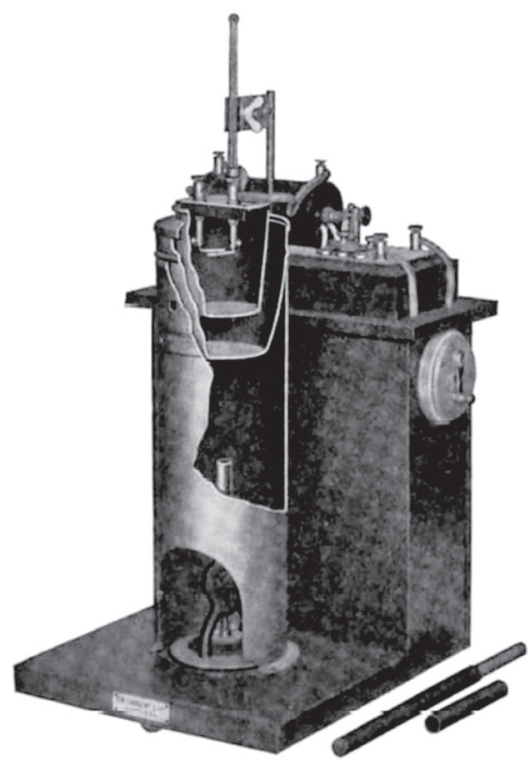

a

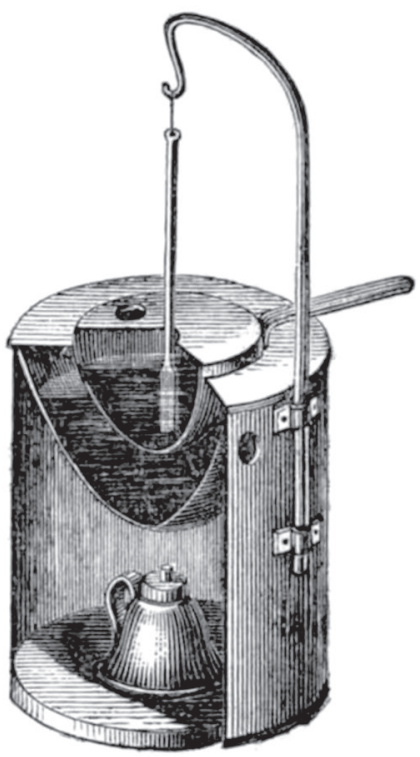

б

Рис. 21. Тестер Скотта (а) [87-89], французский полузакрытый нафтометр (б) [90] 


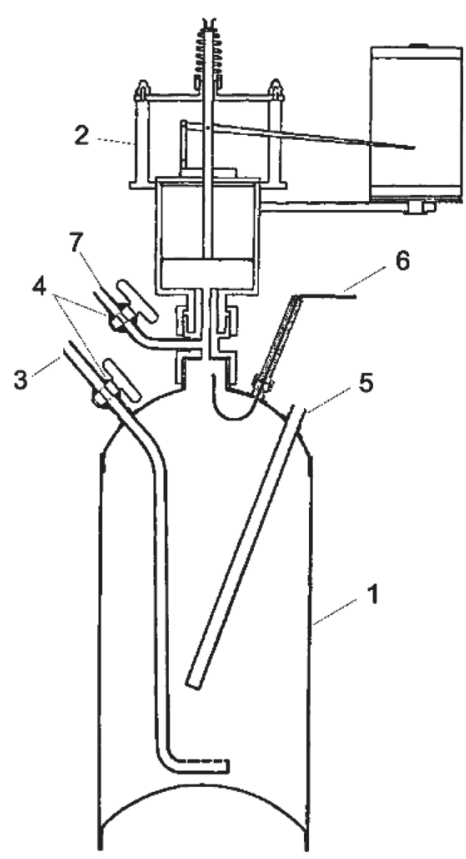

Рис. 22. Тестер Брэдли-Хэйла [91]

Перед тестом на вспышку осуществляется кратковременный барботаж воздуха, после чего пропускается электрическая искра. В случае вспышки фиксируется температура и избыточное давление внутри сосуда. При отрицательном результате испытание повторяют с шагом 5 ํ $\mathrm{F}$ [91].

Фактически аппарат Брэдли-Хэйла является прообразом современных взрывных цилиндров, которые позволяют определять ни один показатель пожаровзрывоопасности, а несколько, поэтому данная конструкция приборов для определения температуры вспышки также относится к классу комбайнов. Он также является прародителем приборов для определения температурных пределов воспламенения [92-94], которые впервые появились в СССР в 50-х годах прошлого столетия [95-97].

\section{Заключение}

Судьба паровых аппаратов сложилась поразному, некоторые были забыты сразу после своего рождения, но и большинство из них имели ограниченное практическое применение до конца 19-го и начала 20-го столетий. Зависимость давления насыщенного пара от температуры вспышки, на которой были построен принцип действия паровых аппаратов без источника зажигания, послужило основой для разработки расчетных методов этого показателя пожаровзрывоопасности $[98,99]$. Идея интенсификации образования паровоздушной смеси путем барботажа воздуха через слой горючей жидкости, заложенная в основе работы открытых паровых тестеров, используется в нефтехимической промышленности для непрерывного определения температуры вспышки [100-106]. Стремление изобретателей закрытых паровых нафтометров определить «истинную» (самую низшую температуру вспышки) осветительных масел и других горючих жидкостей создало предпосылки для появления новых показателей пожаровзрывоопасности - низший и высший температурные пределы воспламенения [92, 93].

В заключительной части нашей серии будут рассмотрены нафтометры типа закрытый тигель и дистилляционного принципа действия.

\section{Лuтература}

1. Алексеев С.Г., Смирнов В.В., Барбин Н.М. Пожаровзрывобезопасность. 2012. Т. 21. № 5. С. 35.

2. Алексеев С.Г., Смирнов В.В., Барбин Н.М. Техносферная безопасность. 2016. № 4(13). с. 35.

3. Алексеев С.Г., Смирнов В.В., Барбин Н.М. История науки и техники. 2017. № 12. С. 60.

4. Alexeev S., Smirnov V., Barbin N., Alexeeva D. Process Safety Progress. 2018. V. 37. №2. P. 230. Doi: 10.1002/ prs. 11949 .

5. Алексеев С.Г., Смирнов В.В., Барбин Н.М. Вопросы истории естествознания и техники. 2018. Т. 39. №3. C. 508. Doi: 10.31857/S020596060001121-5.

6. Алексеев С.Г., Смирнов В.В., Барбин Н.М. Российский химический журнал. 2018. Т. 62. № 3. С. 71-87.

7. Redwood B. Petroleum: its Production and Use. London: D. van Nostrand Publ. 1887. 210 p.

8. Thomson J.H., Redwood B. Handbook on Petroleum. London: Charles Griffin and Co. 1913. 428 p.

9. Redwood B. Petroleum. London: Charles Griffin and Co. 1913. V. 2. 428 p.

10. Smith H.J., Jones W. Pat. 35184 USA. 1862.

11. Tagliabue J. Pat. 36488 USA. 1862.

12. Tagliabue G. Pat. 36826 USA. 1862.

13. Parrish E. In: Proceedings of the American Pharmaceutical Association at the Tenth Annual Meeting Held in Philadelphia. Philadelphia: Merrihew\&Thompson. 1862. p. 206.

14. Parrish E. Zeitschrift für analytische Chemie. 1864. bd. 3. S. 228. Doi: 10.1007/BF01346046.

15. Лисенко К.И. Нефтяное производство, составленное по новъйшим даннымъ. С.-Петербургъ: Типографія брат. Пантелеевыхъ. 1878. $281 \mathrm{c.}$

16. Tate A.N. Petroleum and its Products. London: John W. Davies. 1863. p. 86.

17. Gibbons W.S. Kerosene oil: What it is; with causes and prevention of accidents in its use, together with upwards of fifty analyses and experiments with samples sold in Melbourne. Melbourne: F. Bailliere, Publisher \& Importer. $1862.33 \mathrm{p}$.

18. Peckham S.F. Report on the Production, Technology, and Uses of Petroleum and its Products. Washington: Census Office of Department of Interior. 1885. p. 223. 
19. Лисенко К.И. Горный журналъ. 1887. Т. 1 (Март). C. 478.

20. Allen I.C., Crossfield A.S. The flash point of oils. Methods and apparatus for its determination: Technical Paper №49. Petroleum Technology №10. Department of Interior. Bureau of Mines. Washington, Government Printing Office. 1913. 31 p.

21. Day A.A. Third annual report of the secretary of the State board of health of the State Michigan for the fiscal year ending Sept. 30, 1875. Lansing: W.S. George \& Co., State printers and Binders. 1876. $95 \mathrm{p}$.

22. Davy H. Proceedings of the Royal Society of London. 1815. V. 2. P. 30. Doi: 10.1098/rspl.1815.0024.

23. Davy H. Philosophical Transactions of the Royal Society of London. 1816. V. 106. Part I. P. 1. Doi: 10.1098/ rstl.1816.0001.

24. Britton L.G. Process Safety Progress. 2002. V. 21. № 1. P. 1. Doi: 10.1002/prs.680210104.

25. Scientific American. 1871. V. 25. № 1. P. 162.

26. Vander Weyde p.H. Dingler's Polytechnisches Journal. 1871. bd. 202. S. 301-302.

27. Salleron M.J., Urbain V. Comptes Rendus. 1866. V. 62. P. 43.

28. Salleron M.J., Urbain V. Dingler's Polytechnisches Journal. 1866. bd. 181. №47. S. 397.

29. Salleron M.J., Urbain V. Les Mondes. 1866. V. 10. № 1. P. 127.

30. Hager H. Zeitschrift für analytische Chemie. 1866. bd. 5. №1. S. 245. Doi: 10.1007/BF01302487.

31. Wagner's Jahresbericht über die Leistungen der Chemischen Technologie. 1866. bd. 12. S. 663.

32. Thorpe E. A Dictionary of Applied Chemistry. New York: Longmans, Green, and Co. 1913. V. 4. P. 139-154.

33. Chemisch-Technische Analyse / herausgegeben von J. Post. Braunschweig: Druck und Verlag von Friedrich Vieweg und Sohn. 1888-1889. bd. 1. S. 281, 305 p.

34. Brannt W.T. Petroleum: its History, Origin, Occurrence, Production, Physical and Chemical Constitution, Technology, Examination and Uses. Together with the Occurrence and Use of Natural Gas / by ed. H. Hoefer, A. Veuth. Philadelphia: Henry Carey Baird \& Co., Industrial Publishers, Booksellers and Importers. 1895. $781 \mathrm{p}$.

35. Elliott A.H. Report of State Board of Health of New York №45. Albany: Weed, Parsons and Co., Printers. 1882. 44 p.

36. Redwood B., Holloway G.T. Petroleum. London: Charles Griffin \& Co. 1896. V. 2. 500 p.

37. Dingler's Polytechnisches Journal. 1881. bd. 240. S. 129.

38. Elliott A.H. Transactions of the New York Academy of Sciences. 1881-82. V. 1. P. 137.

39. Engler $C$., Haass $R$. Zeitschrift für analytische Chemie. 1881. bd. 20. № 1. S. 136. Doi: 10.1007/BF01374603.

40. Müller J. Lehrbuch der Physic und Meteorologie. Braunschweig: Druck und Verlag von Friedrich Vieweg und Sohn. 1862. bd. 1. S. 190.

41. Pat. 104798 (US).

42. The Engineer. 1873. (17 October). P. 252.

43. Blair J.B. Pat. 139654 USA. 1873.
44. Meusel Ed. Polytechniches Centralblatt. 1872. №5 S. 310 .

45. Meusel Ed. Chemisches Zentralblatt. 1872. №15. S. 234.

46. Meusel Ed. Wagner's Jahresbericht über die Leistungen der Chemischen Technologie. 1872 (publ. 1873). bd. 18. S. 847.

47. Byasson M.H. Comptes Rendus. 1871. V. 73. P. 609.

48. Stahlschmidt C. Bolley's Handbuch der TechnischenChemischen Untersuchungen. Leipzig: Verlag von Arthur Felix. 1879. S. 668, 740.

49. Liebermann L. Zeitschrift für analytische Chemie. 1882. bd. 21. №1. S. 321. Doi: 10.1007/bf01356472.

50. Stoddard J.T. American Chemical Journal. 1882. V. 4. №4. P. 285.

51. Stoddard J.T. Berichte Der Deutschen Chemischen Gesellschaft. 1882. Bd 15. №2. S. 2555. Doi: 10.1002/ cber. 188201502216 .

52. Stoddard J.T. The Popular Science Monthly. 1883. V. 24 (November). P. 461.

53. Haskins H.D. Organic Chemistry Including Certain Portions of Physical Chemistry for Medical, Pharmaceutical, and Biological Students. New York: J. Wiley \& Sons. 1917. P. 122.

54. Beilstein F. Zeitschrift für analytische Chemie. 1883. bd. 22. № 1. S. 309. Doi: 10.1007/BF01338143.

55. Journal of the Society of Chemical Industry. 1884. V. 3. P. 235.

56. Journal of the Society of Chemical Industry. 1884. V. 3. P. 161.

57. Смоленскій П.О. Простьшіе способы изсльдованія и оцЊнки доброкачествнности съестныхъ припасовъ, напитковъ, воздуха, воды, почвы, жилищъ, освђтительныхъ матеріаловъ и проч. С.-Петербургъ: Типографія Я. Трей, 1908. 598 с.

58. Beythien A., Hempel H. Chemische Revue Über Die Fett- Und Harz-Industrie. 1908. bd. 15. №3. s. 54. Doi:10.1002/lipi.19080150306.

59. Beilstein F. American Chemical Journal. 1883-84. V. 5. №6. P. 459.

60. Долинин В.К. Горный журналъ. 1887. Т. 1 (Март). c. 442 .

61. Stoddard J.T. American Chemical Journal. 1884-85. V. 6. № 1. P. 18.

62. Полное собрание законовъ Россіиской имперіи. Собраніе третіе. С.-Петербургъ: 1891. Т. 11. С. 381.

63. Труды техническаго комитета Главного Управления неокладныхъ сборовъ и казенной продажи питей. С.-Петербургъ, Изданіе Главнаго Управленія неокладныхъ сборовъ и казенной продажи питей. 1908. T. 21. C. 63

64. Hessler J.C. First year of sciences. Chicago: Benj. H Sanborn \& Co. 1914. P. 115.

65. Mack E., Boord C.E., Barham H.N. Industrial \& Engineering Chemistry. 1923. V. 15. №9. P. 963. Doi: 10.1021/ie50165a046.

66. Bernstein A. Pat. 7508 Deutschen Reiche. 1879.

67. Bernstein A. Pat. 8389 Deutschen Reiche. 1879.

68. Bernstein A. Pat. 240365 USA. 1881.

69. Braun O. Pat. 14022 Deutschen Reiche. 1880. 
70. Wright $R$. Journal of the Chemical Society. Transactions. 1922. v. 121. p. 2247. Doi: 10.1039/CT9222102247.

71. Saybolt G.M. Pat. 245568 USA. 1881.

72. Braun O. Pat. 18076 Deutschen Reiche. 1881.

73. Dingler's Polytechnisches Journal. 1882. bd. 243. S. 476.

74. Hörler H. Dingler's Polytechnische Journal. 1879. bd. 234. S. 52.

75. Journal of the Chemical Society, Abstracts. 1880. V. 38. P. 199.

76. Pharmazeutische Zentralhalle für Deutschland. 1880. bd. 21. №3. S. 23.

77. Pharmazeutische Zentralhalle für Deutschland. 1881. bd. 22. №47. S. 518.

78. Haass R. Chemische Industrie. 1880. bd. 3. №4. S. 123.

79. Berichte der deutschen chemischen Gesellschaft. 1881. bd. 14. №1. S. 283. Doi: 10.1002/cber.18810140159.

80. Industrie-Beitung. 1881. S. 79.

81. Эрисман Ф.Ф. Курсъ гигіены. Москва: Типографія А.А. Карцева. 1887. Т. 2. С. 235.

82. Elsner F. Die Praxis des Chemikers. Hamburg: Verlag von Leopold Vess. 1893. S. 396.

83. Engler C. Chemische Industrie. 1880. bd. 3. №2. S. 49.

84. Pat. 620654 (Fr).

85. Thörner W. Chemiker Zeitung. 1886. bd. 10. №38. S. 582.

86. American Engineer. 1882. V. 4. № 19. P. 208.

87. Journal of Industrial \& Engineering Chemistry. 1910. V. 2. № 11. p. 482. Doi: 10.1021/ie50023a021.

88. Cross R. A Bulletin of Kansas City Testing Laboratory. 1919. № 15. P. 318.

89. E.H. Sargent \& Company Price List №20 of Scientific Laboratory Apparatus. Chicago: E.H. Sargent \& Co. 1914. P. 224.

90. Elliott G.H. Report of a Tour of Inspection of European Light-House Establishments, Made in 1873. Washington: Government Printing Office. 1874. 11 p.

91. Bradley W.P., Hale C.F. The Journal of Industrial and Engineering Chemistry. 1909. V. 1. №6. P. 345. Doi: $10.1021 /$ ie50006a006.
92. ГОСТ 12.1.044-89. ССБт. Пожаровзрывоопасность веществ и материалов. Номенклатура показателей и методы их определения. Москва: Стандартинформ. 2006. 99 с.

93. ASTM E1232-91 (1996). Standard test method for temperature limit of flammability of chemicals. URL: https//www.astm.org/data-base.cart/historical/e123291r96.htm (дата обращения: 12.04.19).

94. Михеев Г.М. Пат. 2178885 РФ. 2002.

95. Соколов А.В., Кузьменок Д.Ф., Масленников Н.В. A.c. 114819 CCCP. 1958.

96. Годжелло М.Г., Демидов П.Г., Джалалов Е.М. Коршак Э.В., Рябов И.В. Легковоспламеняющиеся и горючие жидкости. Справочник. Москва: изд-во Министерства коммунального хозяйства РСФСР. 1956. $112 \mathrm{c}$.

97. Баратов А.Н., Годжелло М.Г. Оценка пожарной опасности производств, связанных с применением горючих газов и жидкостей. Москва: изд-во Министерства коммунального хозяйства РСФСР. 1961. $84 \mathrm{c}$.

98. Алексеев С.Г., Смирнов В.В., Барбин Н.М. Пожаровзрывобезопасность. 2012. Т. 21. № 10. С. 2135.

99. Беззапонная О.В., Алексеев С.Г., Акулов А.Ю., Pblбаков Ю.С., Головина Е.В. Безопасность жизнедеятельности. 2016. №8 (188). с. 36.

100. Phoon L.Y., Mustaffa A.A., Hashim H., Mat R. Industrial \& Engineering Chemistry Research. 2014. V. 53. P. 1253. Doi: 10.1021/ie501233g.

101. Greanias E.C. Pat. 2746285 USA. 1956.

102. Greanias E.C. Pat. 2746286 USA. 1956.

103. Jacobs R.B. Pat. 2971370 USA. 1961.

104. Speight J.G. The Chemistry and Technology of Petroleum. Boca Raton: CRC Press Taylor \& Francis Group. 2014. 939 p.

105. Yagi M. Pat. 4380488 Japan. 2009.

106. Kent and Riegel's Handbook of Industrial Chemistry and Biotechnology / by ed. J.A. Kent. New York: Springer Science+Business Media. 2007. 1906 p. 